\title{
Prediksi Jumlah Pasien Positif Covid-19 Di Indonesia Menggunakan Model Berbasis Spasio Temporal GSTAR Orde Satu
}

\author{
(Forecasting The Number of Confirmed COVID 19 in Indonesia by Using GSTAR Spatio-Temporal \\ Model)
}

\author{
Maisuri $^{1}$, Asrirawan $^{2 *}$, Ahmad Ansar ${ }^{3}$ \\ ${ }^{1,3}$ Program Studi Matematika, Universitas Sulawesi Barat, Indonesia \\ ${ }^{2}$ Program Studi Statistika, Universitas Sulawesi Barat, Indonesia \\ Alamat: Perumahan Rusung-rusung, Kabupaten Majene, Provinsi Sulawesi Barat \\ E-mail: asrirawan@unsulbar.ac.id
}

\begin{abstract}
ABSTRAK
Coronavirus Disease 2019 (COVID-19) atau dinamakan Sars-CoV-2 adalah virus pandemik yang pertama kali yang tersebar di China dan merupakan Virus yang termasuk kedalam zoonosis (ditularkan antara manusia dan hewan). Penyebaran COVID-19 dapat melalui droplet (partikel kecil) saat seseorang berbicara ataupun bersin, udara, dan permukaan yang terkontaminasi. Sehingga faktor utama Penyebab Peningkatan COVID-19 diantaranya meningkatnya pergerakan, aktivitas, dan interaksi penduduk, seperti akaktivitas di transportasi publik dan tempat kerja, kemudian adanya faktor varian baru COVID-19 serta keterkaitan pada waktu sebelumnya. Proses penyebaran dari lokasi ke lokasi lain (transmisi) melibatkan proses spasial. Data deret waktu COVID-19 dapat dimodelkan dengan model GSTAR berbasis spasio temporal pada 2 pulau di Indonesia yakni Pulau Jawa, dan Pulau Sulawesi. Bobot yang digunakan dalam penelitian ini adalah bobot invers jarak dengan Model GSTAR yang sesuai adalah GSTAR $(1,1)$. Tingkat ramalan model GSTAR tersebut untuk semua data testing dan training dengan bobot Invers Jarak yang memiliki RMSE terkecil berada pada model GSTAR Lokasi Pulau Jawa yaitu sebesar 0,40255. Sedangkan ramalan model GSTAR yang memiliki nilai RMSE terbesar adalah Pulau Sulawesi yakni 1,616303.
\end{abstract}

Kata kunci: Bobot Invers Jarak, COVID-19, GSTAR, Spasio-Temporal

\begin{abstract}
Coronavirus Disease 2019 (COVID-19) or called Sars-CoV-2 is a pandemic virus that first spread in China and a virus that is included in zoonoses (transmitted between humans and animals). The spread of COVID-19 can be through droplets (small particles) when someone talks or sneezes, air, and contaminated surfaces. So that the main factors causing the increase in COVID-19 include increased movement, activity, and interaction of the population, such as activities in public transportation and the workplace, then the new variant of COVID-19 and the linkages in the previous time. The process of transmission from one location to another (transmission) involves a spatial process. The COVID-19 time series data can be modeled with the spatio-temporal based GSTAR model on two islands in Indonesia, namely Java Island and Sulawesi Island. The weight used in this study is the inverse distance weight with the appropriate GSTAR model being GSTAR $(1,1)$. The forecast level of the GSTAR model for all testing and training data with Inverse Distance weights which has the smallest RMSE is in the GSTAR model for Location Java, which is 0,40255. While the forecast for the GSTAR model which has the largest RMSE value is Sulawesi Island, which is 1,616303
\end{abstract}

Keywords: Distance Inverse Weighted, COVID-19, GSTAR, Spatio-Temporal

\section{PENDAHULUAN}

Sejak ditetapkan sebagai wabah pandemik, virus corona baru (COVID-19) telah menjadi masalah kesehatan yang cukup serius bagi semua negara yang ada di dunia. Penularan virus ini cukup signifikan bepengaruh pada manusia yang digolongkan termasuk virus RNA dari hasil penelitian. Virus ini termasuk family virus korona, yang menyebabkan terjadinya infeksi pada sistem pernapasan manusia (Zhu et al., 2020). WHO telah menyatakan bahwa munculnya virus COVID-19 sebagai darurat atau masalah utama kesehatan bagi masyarakat di dunia pada tanggal 30 Januari dan menjadi perhatian pada tingkat internasional. Selain itu, WHO juga telah mengumumkan bahwa virus COVID-19 sebagai wabah pandemi sejak tanggal 12 Maret 2020. Jumlah penambahan kasus confirmed COVID-19 cukup pesat dan jumlah orang yang telah terinfeksi atau terkonfirmasi menderita virus tersebut di dunia telah mencapai 182.988.346 kasus dan 3.964.023 kematian. Dengan kasus terbanyak berada di Amerika Serikat (34.549.128 kasus), India (30.410.577 kasus), Brasil (18.559.164 kasus). (WHO, 2021). Di tingkat ASEAN Indonesia menduduki posisi pertama penyumbang 
kasus COVID-19 disusul oleh Filipina (1.412.542 kasus), Malaysia (751.979 kasus), Thailand (259.301 kasus). (Kemenkes RI, 2021). Sebagai Negara terpadat dan berkembang keempat di dunia, Indonesia diprediksi akan terdampak oleh virus ini dalam jangka waktu yang lebih lama. Sejak Presiden Joko Widodo pertama kali mengumumkan kepada masyarakat Indonesia bahwa pada telah menemukan dua kasus infeksi COVID-19 di Indonesia, jumlah kasus COVID-19 di Indonesia terus mengalami peningkatan, tercatat sebanyak 2.178.272 kasus positif dan 58.491 kematian per tanggal 30 Juni 2021 dengan kasus terbanyak berada di DKI Jakarta (543.468 kasus), Jawa Barat (381.455 kasus), Jawa Tengah (253.939 kasus) (Kemenkes RI, 2021). Virus ini menyebabkan pembatasan kegiatan masyarakat untuk menghindari terjadinya transmsi antar manusia.

Untuk mengatasi permasalahan terjadinya penyebaran atau transmisi COVID-19 antar manusia dari waktu ke waktu dan antar lokasi maka diperlukan sebuah model pemetaan yang berbasis spatio-temporal. Model Generalized Space Time Autoregressive (GSTAR) merupakan salah satu model yang berbasis space time untuk memodelkan, memprediksi dan meramalkan data yang memiliki keterkaitan antar waktu sebelumnya dan keterkaitan dengan lokasi yang berdekatan. Pfeifer dan Deutsch (1980) memperkenalkan model ini sebagai hasil pengembangan model Space Time Autoregressive (STAR). Model GSTAR lebih fleksibel dibandingkan dengan model STAR karena mengasumsikan bahwa parameter autoregressive pada model GSTAR berbeda untuk setiap lokasi yang digunakan, sehingga model ini sesuai untuk diterapkan pada lokasi yang mepunyai karakteristik yang heterogen, (Wutsqa et al. (2010) dalam Ana Nur Islamiyah, et al., 2018). Model ini banyak digunakan pada bidang kesehatan untuk memprediksi atau meramalkan banyaknya jumlah penderita penyakit tertentu untuk periode selanjutnya sehingga pemerintah dapat mengevaluasi dan mengambil kebijakan untuk mengatasi permasalahan kesehatan tersebut. Berkaitan dengan itu, maka metode ini dapat dilakukan dalam penelitian terhadap jumlah positif COVID-19 di 6 (enam) kabupaten yang ada di Provinsi Sulawesi Barat beberapa bulan terakhir untuk mendapatkan model prediksi kejadian dengan memperhatikan tempat dan waktu (spatio-temporal). Beberapa penelitian yang berkaitan dengan metode GSTAR diantaranya Ana Nur Islamiyah DKK (2018) menerapkan pada pada Penderita TB Paru (BTA+) yang ada di Provinsi DKI Jakarta dan didapatkan model GSTAR $(1 ; 1)$ menggunakan pembobot lokasi normalisasi korelasi silang. Yusti Andriani dan Nuri Wahyuningsih (2013) menerapkan pada jumlah penderita DBD di Kabupaten Kediri. Sedangkan Gumanti (2010) menerapkan pada jumlah penderita DBD di Kota Surabaya dan didapatkan model GSTAR $(1 ; 1)$ dengan menggunakan bobot seragam sebagai model terbaik untuk meramalkan kejadian TB Paru tersebut. Penelitian ini bertujuan untuk melihat efek spasial penyebaran COVID-19 di wilayah jawa dan sulawesi sehingga pemerintah bisa mengantisipasi transmisi COVID-19 antar wilayah.

\section{METODE}

\section{Data dan Sumber Data}

Data yang digunakan dalam penelitian ini adalah data sekunder yang diperoleh dari website AndraFarm.com. Data ini berupa laporan kasus positif (confirmed) COVID-19 di 8 Provinsi yang ada di Indonesia yaitu Pulau Jawa (Bali, DI Yogyakarta, DKI Jakarta, Jawa Barat dan Jawa Tengah) dan Pulau Sulawesi (Sulawesi Selatan, Sulawesi Tenggara dan Sulawesi Utara) dari rumah sakit daerah maupun swasta dan balai pengobatan ke Dinas Kesehatan RI. Periode data kasus positif COVID-19 yang digunakan yaitu dimulai pada tanggal 8 Juli 2020 hingga 30 Juni 2021. Lokasi tersebut dipilih sebagai beberapa lokasi yang memiliki keragaman pertambahan atau kenaikan jumlah kasus yang cukup signifikan dan berada pada zona merah dan hitam. Data harian COVID-19 dibagi menjadi data in sample dan data out sample. Data in sample digunakan mulai tgl 8 Juli 2020 sampai dengan 19 April 2021. Sedangkan data out sample mulai tg1 20 April 2021 sampai dengan tgl 30 Juni 2021.

\section{Model Time Series}

Model time series merupakan sebuah model waktu yang menjelaskan perilaku dari serangkaian waktu berdasarkan nilai lag yang dipilih dan mungkin satu atau lebih input. Sebuah contoh sederhana hubungan lag dengan model time series bisa menjadi cukup kompleks. Misalnya, model ARIMA (p,d,q) adalah model prediksi atau peramalan yang termasuk dalam kelompok model linier dan dapat diterapkan pada data yang mempunyai unsur atau pola non-musiman maupun musiman. Model ARIMA (p,d,q) dapat dilihat pada persamaan (1) (Wei,2006)

$$
\phi_{p}(B)(1-B)^{d} Z_{t}=\delta_{0}+\theta_{q}(B) a_{t}
$$

dimana, 
$\phi_{p}(B)=1-\phi_{1} B-\cdots-\phi_{p} B^{p}$ dan $\theta_{q}(B)=1-\theta_{1} B-\cdots-\theta_{q} B^{q}$

Model ARIMA $(\mathrm{P}, \mathrm{D}, \mathrm{Q})^{\mathrm{S}}$ digunakan unutk data yang mengandung pola atau unsur musiman $\mathrm{S}$ dengan differencing atau pembeda ber-orde D. Secara umum, model ARIMA yang multiplikatif atau model yang mengandung unsur musiman dan non musiman yang ditulis sebagai model ARIMA $(\mathrm{p}, \mathrm{d}, \mathrm{q})(\mathrm{P}, \mathrm{D}, \mathrm{Q})^{\mathrm{S}}$ adalah dapat dilihat pada persamaan (2):

$$
\phi_{p}(B) \Phi_{p}\left(B^{S}\right)(1-B)^{d}\left(1-B^{S}\right)^{D} Z_{t}=\delta_{0}+\theta_{q}(B) \Theta_{e}\left(B^{S}\right) a_{t}
$$

Keterangan:

$$
\begin{aligned}
& \phi_{p}(B)=1-\phi_{1} B-\cdots-\phi_{p} B^{p} \\
& \Phi_{p}\left(B^{S}\right)=1-\Phi_{1} B^{S}-\cdots-\Phi_{p} B^{p s} \\
& \theta_{q}(B)=1-\theta_{1} B-\cdots-\theta_{q} B^{q} \\
& \Theta_{e}\left(B^{S}\right)=1-\Theta_{1} B^{S}-\cdots-\Theta_{e} B^{e s} \\
& (1-B)^{d}=\text { pembeda non musiman ber-orde d } \\
& \left(1-B^{S}\right)^{D}=\text { pembeda musiman S ber-orde D } \\
& \theta_{0}=\mu\left(1-\phi_{1}-\cdots-\phi_{p}\right) \\
& \mu=\text { nilai rata-rata data yang sudah stasioner (dengan differencing) } \\
& a_{t}=\text { Sisaan white noise dengan nilai rataan } 0 \text { dan varians } \sigma_{a}^{2}, a_{t} \sim W N\left(0, \sigma_{a}^{2}\right)
\end{aligned}
$$

\section{Multivariate Time Series}

Multivariate time series adalah kumpulan data yang terdiri dari beberapa variabel yang dicatat secara berurutan dan digunakan dari waktu ke-waktu serta berdasarkan urutan dari waktu kejadiannya dengan menggunakan interval waktu yang tetap. (Wei, 2006). Interval tersebut adalah periode dalam satuan tahun, bulan, minggu, hari, jam, menit, detik dan atau menggunakan periode waktu yang lainnya. Kestasioneran data pada model multivariate time series dapat dilihat dari. Plot atau gambar MACF, MPACF, dan Box-Cox digunakan untuk melihat kestasioneran yang sifatnya bisa subjektif. Sehingga, salah satu uji kestasioneran yang dapat digunakan adalah uji Augmented Dickey-Fuller (ADF) baik untuk memeriksa kestasioneran terhadapt varians maupun rataan. Selain itu, Makridakis (1999) juga menyatakan bahwa suatu plot data deret waktu seringkali dapat menggambarkan secara jelas bahwa data tersebut sudah stasioner atau tidak stasioner. Namun, pengujian menggunakan Augmented Dickey Fuller (ADF) lebih efektif dibandingkan dengan menggunakan plot deret waktu.

\section{Model Generalized Space-Time Autoregressive (GSTAR)}

Salah satu pengembangan dari model Space Time Autoregressive (STAR) adalah model Model Generalized Space Time Autoregressive (GSTAR) $\left(\mathrm{p} ; \boldsymbol{\lambda}_{\mathrm{k}}\right)$. Untuk pertama kali, Model STAR dikembangkan oleh Pfeifer dan Deutsch (1980) dalam Siswanto, E. dkk., (2019). Akan tetapi, model tersebut mempunyai kelemahan yaitu terdapat asumsi-asumsi parameter autoregressive yang memiliki nilai yang sama untuk semua lokasi yang digunakan, sehingga model tersebut akan lebih tepat untuk lokasi dengan karakteristik yang tidak heterogen (homogen) (Borovkova et al. 2008). Selain itu, model GSTAR lebih fleksibel dalam menentukan orde autoregressive (p). Matriks pembobot lokasi pada model GSTAR adalah matriks yang digunakan untuk melihat keterkaitan lokasi atau spasial $\left(\lambda_{\mathrm{k}}\right)$ dengan sejumlah data pengamatan $(t)$ pada tiap $\mathrm{N}$ lokasi pada suatu ruang $(\mathrm{i}=1,2, \ldots, \mathrm{N})$ terhadap periode waktu ke-t. (Wutsqa et al. 2010 dalam Siswanto, E. dkk., 2019).

Jika diketahui sebuah deret $\{Z(t): t=0, \pm 1, \pm 2, \cdots, T\}$ merupakan sebuah multivariate time series dari $\mathrm{N}$ komponen, maka model GSTAR yang mempunyai orde autoregressive (p) dengan orde spasial $\lambda_{1}, \lambda_{1}, \cdots, \lambda_{p}$ $\operatorname{GSTAR}\left(p ; \lambda_{1}, \lambda_{1}, \cdots, \lambda_{p}\right)$ dapat dilihat pada persamaan (6) (Wutsqa dan Suhartono, 2010):

$$
\mathbf{Z}(t)=\sum_{s=1}^{p}\left(\boldsymbol{\Phi}_{s 0}+\sum_{k=1}^{\lambda s} \boldsymbol{\Phi}_{s k} \mathbf{W}^{(k)}\right) \mathbf{Z}(t-s)+\mathbf{e}(t)
$$

dengan nilai $\boldsymbol{\Phi}_{s 0}=\operatorname{diag}\left(\phi_{s 0}^{1}, \cdots, \phi_{s 0}^{N}\right), \boldsymbol{\Phi}_{s k}=\operatorname{diag}\left(\phi_{s k}^{1}, \cdots, \phi_{s k}^{N}\right), \mathbf{e}(t)$ yang berdistribusi i.i.d. (identik, independen dan berdistribusi) dengan nilai rataan $E[e(t)]=0$ dan kovarians $E\left[e(t) e(t)^{\prime}\right]=\Sigma$. Nilai 
pembobot harus memenuhi syarat $\sum_{j \neq i} w_{i j}^{(k)}=1$ dan $w_{i i}^{(k)}=0$. Misalnya, persamaan untuk model GSTAR yang mempunyai orde waktu dan orde spasial satu dan menggunakan tiga titik lokasi yang berbeda dapat dilihat pada persamaan (7).

$$
\mathbf{Z}(\mathbf{t})=\boldsymbol{\Phi}_{10} \mathbf{Z}(t-1)+\boldsymbol{\Phi}_{11} \mathbf{W}^{(1)} \mathbf{Z}(t-1)+\mathbf{e}(t)
$$

dan jika diubah ke dalam bentuk matriks, maka persamaan (7) menjadi persamaan (8):

$$
\left(\begin{array}{l}
Z_{1}(t) \\
Z_{2}(t) \\
Z_{3}(t)
\end{array}\right)=\left(\begin{array}{ccc}
\phi_{10} & 0 & 0 \\
0 & \phi_{20} & 0 \\
0 & 0 & \phi_{30}
\end{array}\right)\left(\begin{array}{l}
Z_{1}(t-1) \\
Z_{2}(t-1) \\
Z_{3}(t-1)
\end{array}\right)+\left(\begin{array}{ccc}
\phi_{11} & 0 & 0 \\
0 & \phi_{21} & 0 \\
0 & 0 & \phi_{31}
\end{array}\right)\left(\begin{array}{ccc}
0 & w_{12} & w_{13} \\
w_{21} & 0 & w_{23} \\
w_{31} & w_{32} & 0
\end{array}\right)\left(\begin{array}{l}
Z_{1}(t-1) \\
Z_{2}(t-1) \\
Z_{3}(t-1)
\end{array}\right)+\left(\begin{array}{l}
e_{1}(t) \\
e_{2}(t) \\
e_{3}(t)
\end{array}\right) \ldots
$$

Untuk model GSTAR ( $\mathrm{p}_{1}$ ) dapat dilihat pada persamaan (9) (Borovkova, Lopuhaä,Nurani,2002):

$$
\mathbf{Z}(t)=\sum_{s=1}^{p}\left(\boldsymbol{\Phi}_{s 0}+\boldsymbol{\Phi}_{s 1} \mathbf{W}\right) \mathbf{Z}(t-s)+\mathbf{e}(t)
$$

\section{Bobot Lokasi Model GSTAR}

Penentuan bobot dalam analisis deret waktu yang berbasis spatio-temporal seperti model GSTAr masih menjadi permasalah utama dalam pemodelan tersebut. Suhartono dan Atok (2006) menyatakan bahwa terdapat berbagai macam meentukan bobot dalam model GSTAR. Pada penelitian ini, bobot yang digunakan adalah bobot seragam dan bobot invers jarak. Bobot lokasi seragam mengasumsikan bahwa semua lokasi bersifat homogen sehingga setiap lokasi memiliki nilai yang sama. Penentuan nilai bobot pada bobot lokasi seragam dapat dilihat pada persamaan (10).

$$
w_{i j}=\frac{1}{s_{i}}
$$

dengan $s_{i}$ adalah lokasi-lokasi yang saling berdekatan dengan lokasi lainnya atau lokasi ke-i. Misalnya, matriks pembobot untuk 3 (tiga) lokasi dapat dilihat pada persamaan matriks (11).

$$
\mathbf{W}_{i j}=\left(\begin{array}{ccc}
0 & 1 / 2 & 1 / 2 \\
1 / 2 & 0 & 1 / 2 \\
1 / 2 & 1 / 2 & 0
\end{array}\right)
$$

Pembobotan invers jarak dapat dilakukan dengan menggunakan jarak sebenarnya antar setiap lokasi dengan perhitungan menormalisasi hasil invers jarak sebenarnya. Penentuan nilai bobot lokasi pada bobot invers jarak adalah $W_{i j}=0$ atau 1 dengan menggunakan ketentuan pada persamaan (12):

$$
W_{i j}=\frac{\frac{1}{d_{i j}}}{\sum_{j}^{S} \frac{1}{d_{i j}}},
$$

untuk $j \neq i$ dan $W_{i j}=0$ untuk $i=j$ dengan $d_{i j}$ dapat dirumuskan menjadi persamaan garis linear (13) berikut:

$$
d_{i j}=\sqrt{\left(u_{i}-u_{j}\right)^{2}+\left(v_{i}-v_{j}\right)^{2}}
$$

dimana $d_{i j}$ merupakan jarak lokasi ke-i dank e-j, $\left(u_{i}, u_{j}\right)$ merupakan latitude dan $\left(v_{i}, v_{j}\right)$ merupakan longitude. Untuk menentukan orde pada model GSTAR, model VAR(p) adalah salah satu cara yang dapat dilakukan dengan melihat nilai AIC terkecil (Wustqa et al, 2010). Menurut Tsay (2002) nilai AIC dirumuskan pada persamaan (14):

$$
A I C=\ln \left(\frac{J K S}{N}\right)+\frac{2 K^{2}}{N}
$$

Model GSTAR harus memenuhi asumsi distribusi normal ganda atau model tersebut tidak berkorelasi. Uji Ljung Box Pearce adalah salah satu uji yang dapat diterapkan untuk menguji asumsi tersebut (Wei, 2006). Pengujian kesesuain atau ketepatan model yang digunakan pada penelitian ini adalah menggunakan nilai RMSE atau (Root Mean Square Error) untuk setiap model. Rumus RMSE dirumuskan pada persamaan (15).

$$
R M S E=\sqrt{M S E}=\sqrt{\frac{1}{M} \sum_{t=1}^{M}(Z(t)-\hat{Z}(t))^{2}}
$$

dimana 
$M:$ Jumlah atau banyaknya data.

$\mathrm{Z}(t)$ : data aktual pada waktu ke- $t$.

$\hat{Z}(t)$ : data ramalan pada waktu ke- $t$.

\section{Peramalan Model GSTAR}

Perhitungan ramalan untuk satu tahap kedepan membutuhkan proses yang dapat diilustrasikan. Misalkan data deret waktu univariat $\hat{Z}_{n}(l)$ adalah hasil prediksi atau ramalan satu tahap ke depan dari deret waktu $Z_{n+1}$ dan mengikuti model $\operatorname{ARMA}(1,1)$. Model $\operatorname{ARMA}(1,1)$ dapat dituliskan seperti pada persamaan (16) (Wei,2006).

$$
\left(1-\phi_{1} B\right)\left(Z_{t}-\mu\right)=\left(1-\theta_{1} B\right) a_{t}
$$

Untuk $t=n+l$, diperoleh nilai $Z_{n+1}$ seperti pada persamaan (17).

$$
Z_{n+1}=\mu+\phi_{1}\left(Z_{n+l-1}-\mu\right)+a_{n+l}-\theta_{1} a_{n+l-1}
$$

karena,

$$
\hat{Z}_{n}(l)=\mu+\phi_{1}\left(Z_{n}-\mu\right)-\theta_{1} a_{n}
$$

dan persamaan untuk hasil peramalan pada satu tahap ke depan menjadi,

$$
\begin{aligned}
& \hat{Z}_{n}(l)=\mu+\phi_{1}\left(\hat{Z}_{n}(l-1)-\mu\right) \\
= & \mu+\phi_{1}^{l}\left[Z_{n}-\mu\right]-\phi_{1}^{l-1} \theta_{1} a_{n}, 1 \geq 2
\end{aligned}
$$

Sehingga model peramalan GSTAR seperti pada persamaan (18) berikut:

$$
\hat{\mathbf{Z}}(t)=\sum_{s=1}^{p}\left[\boldsymbol{\Phi}_{s 0} \mathbf{Z}(t-s)+\sum_{k=1}^{\lambda s} \boldsymbol{\Phi}_{s k} \mathbf{W}^{(k)} \mathbf{Z}(t-s)\right]
$$

\section{HASIL DAN PEMBAHASAN}

\section{Analisis Deskriptif Kasus COVID 19}

Analisis karakteristik penyebaran COVID-19 untuk masing-masing Provinsi disajikan dalam bentuk statistika deskriptif dan analisis plot time series dari tanggal 8 Juli 2020 sampai dengan tanggal 30 Juni 2021. Berdasarkan Gambar 1 diperlihatkan bahwa Provinsi dengan rata-rata jumlah positif (confirmed) COVID-19 tertinggi adalah Provinsi DKI Jakarta dengan jumlah kasus terendah 132, dan kasus tertinggi 9.394 jiwa. Provinsi Jambi merupakan Provinsi dengan nilai kasus positif COVID-19 terendah dibandingkan dengan Provinsi lainnya dengan tingkat keragaman sebesar 34,13. Tingkat keragaman kasus confirmed COVID-19 tertinggi berada di Provinsi DKI Jakarta yakni sebesar 1394,6. Semakin besar tingkat keragaman maka jumlah kasus confirmed COVID-19 juga akan semakin bervariasi peningkatannya sehingga mengakibatkan penambahan kasus yang tidak stabil. Hal ini dapat dilihat pada Gambar 2.

\section{Penentuan Model GSTAR Kasus COVID 19}

Data yang digunakan pada penelitian ini adalah data kasus confirmed COVID-19 8 Provinsi di Indonesia tanggal 8 Juli 2020-07 Juli 2021. Menurut (Karlina dkk, 2014) data di masing-masing kota merupakan variable penelitian. Untuk memodelkan data kasus confirmed COVID-19 di Sulawesi Barat, maka data dibagi ke dalam dua bagian, yaitu data dari tanggal 8 Juli 2020 - 30 Juni 2021 dijadikan sebagai data in-sample sedangkan data 01 Juli 2021 - 07 Juli 2021 dijadikan data out-sample. Data in-sample digunakan untuk memodelkan data time series kasus COVID-19 di Indonesia. Langkah awal dalam memodelkan GSTAR adalah mengidentifikasi kestasioneran data, baik stasioner dalam mean maupun stasioner dalam varians. Untuk melihat stasioner data dalam mean maupun varians maka di lakukan unit root test dan memperhatkan plot grafik. Jika dilihat dari grafik atau plot deret waktu diperoleh data untuk semua lokasi tidak stasioner. Sedangkan, berdasarkan hasil pengujian ADF semua data tidak stasioner dengan nilai P-value di atas 0,05, sehingga diperlukan differencing data. 

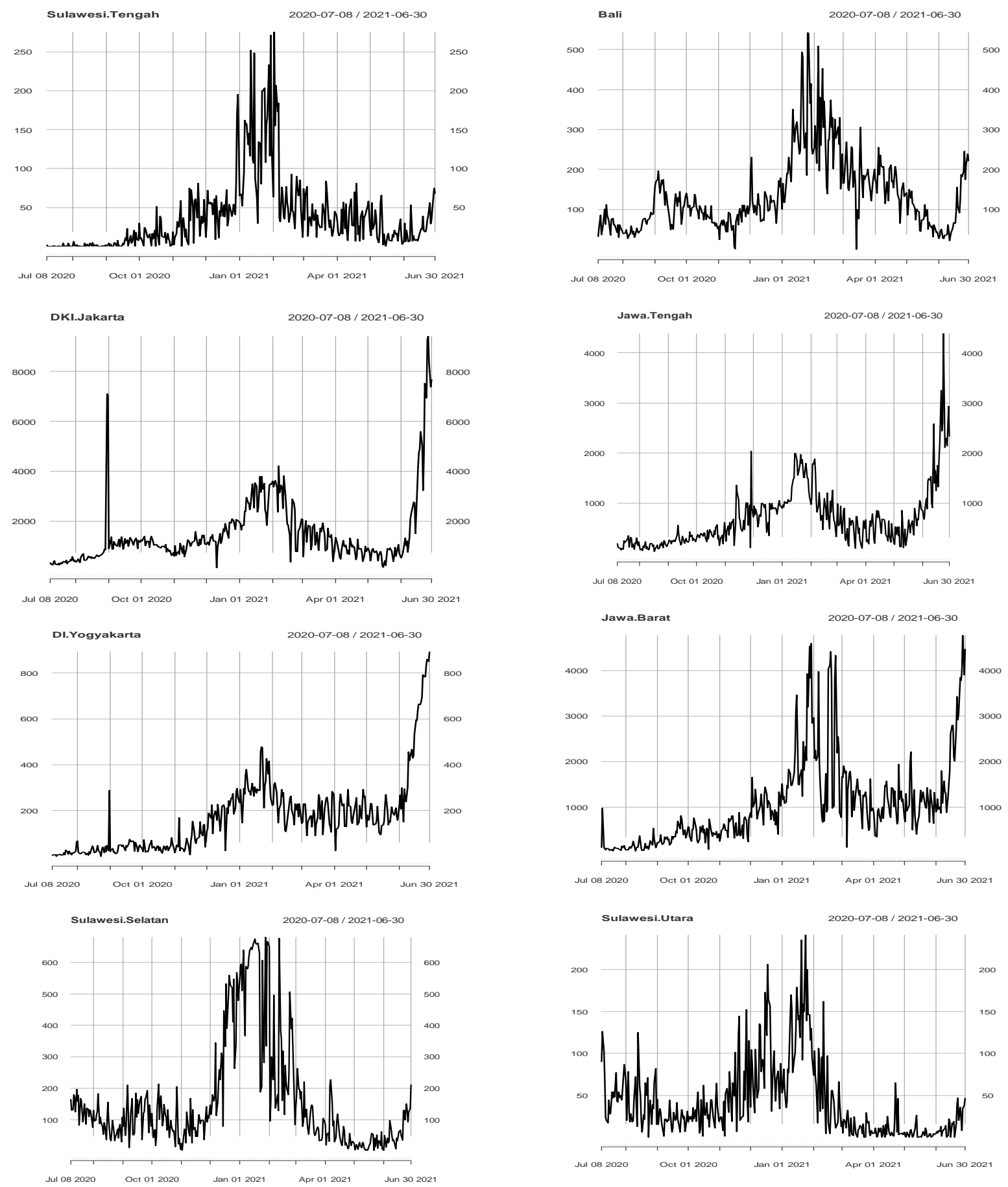

Gambar 1 Plot time series data kasus Convirmed COVID-19 di beberapa Pulau Indonesia

Model GSTAR dengan orde 1 atau GSTAR $\mathrm{I}_{1}$ merupakan model GSTAR yang sesuai untuk data lokasi penelitian. Bobot lokasi yang digunakan pada penelitian ini adalahbobot invers jarak. Pemodelan GSTAR dengan menggunakan bobot invers jarak mengasumsikan bahwa pertambahan jumlah kasus confirmed COVID-19 dipengaruhi oleh jauh dekatnya jarak yang dimiliki dengan lokasi lainnya. Jarak antara dua lokasi yang dekat cenderung mempunyai bobot yang lebih tinggi dibandingkan dengan jarak antara dua lokasi yang lebih jauh. Matriks bobot invers jarak untuk mengestimasi parameter model GSTAR pertama-tama adalah menentukan nilai lattitude dan longitude untuk setiap lokasi. 


\section{Model GSTAR Pulau Jawa}

Tabel 1. Latitude dan Longitude Pulau Jawa

\begin{tabular}{lll}
\hline City & latitude & Longitude \\
\hline Bali & -8.409518 & 115.188919 \\
DI Yogyakarta & -7.797068 & 110.370529 \\
DKI Jakarta & -6.2 & 106.816666 \\
Jawa Barat & -6.943097 & 107.633545 \\
Jawa Tengah & -6.995016 & 110.418427 \\
\hline
\end{tabular}

Berdasarkan Tabel 1 maka dapat dibuat bobot invers jarak dengan langkah sebagai berikut:

1. Melakukan pengkodean A: Bali, B: DI Yogyakarta, C: DKI Jakarta, D: Jawa Barat, E: Jawa Tengah

2. Langkah selanjutnya adalah menghitung $d_{i j}$

3. Langkah selanjutnya adalah menghitung $\mathbf{W}_{i j}$

Dari hasil perhitungan bobot invers jarak di atas maka dapat dibentuk matriks bobot invers jarak sebagai berikut:

Tabel 2. Jarak Antar Provinsi (km)

\begin{tabular}{cccccc}
\hline Lokasi & Bali & DI Yogyakarta & DKI Jakarta & Jawa Barat & Jawa Tengah \\
\hline Bali & 0 & 4,8571573 & 8,6589023 & 7,6963671 & 4,9757823 \\
DI Yogyakarta & 4,8571573 & 0 & 3,8962248 & 2,8671149 & 0,8034809 \\
DKI Jakarta & 8,6589023 & 3,8962249 & 0 & 1,1043026 & 3,6884594 \\
Jawa Barat & 7,6963671 & 2,8671149 & 1,1043026 & 0 & 2,7853659 \\
Jawa Tengah & 4,9757823 & 0,80348094 & 3,6884593 & 2,7853659 & 0 \\
\hline
\end{tabular}

$$
\mathbf{W}_{i j}=\left(\begin{array}{ccccc}
0 & 0,31563657 & 0,177054 & 0,199197 & 0,308112 \\
0,100141 & 0 & 0,124839 & 0,169648 & 0,605369 \\
0,074565 & 0,1657133 & 0 & 0,584673 & 0,175047 \\
0,074532 & 0,200072 & 0,519450 & 0 & 0,205944 \\
0,096822 & 0,599959 & 0,130614 & 0,172963 & 0
\end{array}\right)
$$

Penaksiran parameter model GSTAR dilakukan dengan meregresikan variable $Z_{i}(t)$ dari data harian convirmed COVID-19 di 5 Provinsi pada waktu ke-t sebagai respon. Dengan menggunakan taraf kesalahan sebesar 5\% atau $\alpha=0,05$. Selanjutnya, hasil estimasi parameter model GSTAR menggunakan bobot invers jarak yang signifikan dapat dilihat pada Tabel 3 berikut:

Tabel 3. Estimasi Parameter Model GSTAR Menggunakan Invers jarak untuk Pulau Jawa

\begin{tabular}{cccccl}
\hline Parameter & Estimasi & Kesimpulan & Parameter & Estimasi & Kesimpulan \\
\hline$\phi_{10}^{1}$ & $-0,2450$ & Signifikan & $\phi_{11}^{1}$ & 0,2319 & Signifikan \\
$\phi_{10}^{2}$ & $-0,4217$ & Signifikan & $\phi_{11}^{2}$ & 0,2588 & Signifikan \\
$\phi_{10}^{3}$ & $-0,2633$ & Signifikan & $\phi_{11}^{3}$ & $-0,1933$ & Signifikan \\
$\phi_{10}^{4}$ & $-0,3189$ & Signifikan & $\phi_{11}^{4}$ & 0,1624 & Signifikan \\
$\phi_{10}^{5}$ & $-0,4022$ & Signifikan & $\phi_{11}^{5}$ & 0,1514 & Signifikan \\
\hline
\end{tabular}

Persamaan dalam bentuk matriks GSTAR untuk masing-masing lokasi sebagai berikut:

$$
\begin{aligned}
& \left(\begin{array}{l}
Z_{1}(t) \\
Z_{2}(t) \\
Z_{3}(t) \\
Z_{4}(t) \\
Z_{5}(t)
\end{array}\right)=\left(\begin{array}{ccccc}
\phi_{10}^{1} & 0 & 0 & 0 & 0 \\
0 & \phi_{10}^{2} & 0 & 0 & 0 \\
0 & 0 & \phi_{10}^{3} & 0 & 0 \\
0 & 0 & 0 & \phi_{10}^{4} & 0 \\
0 & 0 & 0 & 0 & \phi_{10}^{5}
\end{array}\right)\left(\begin{array}{l}
Z_{1}(t-1) \\
Z_{2}(t-1) \\
Z_{3}(t-1) \\
Z_{4}(t-1) \\
Z_{5}(t-1)
\end{array}\right)+\left(\begin{array}{ccccc}
\phi_{11}^{1} & 0 & 0 & 0 & 0 \\
0 & \phi_{11}^{2} & 0 & 0 & 0 \\
0 & 0 & \phi_{11}^{3} & 0 & 0 \\
0 & 0 & 0 & \phi_{11}^{4} & 0 \\
0 & 0 & 0 & 0 & \phi_{11}^{5}
\end{array}\right) \\
& \left(\begin{array}{ccccc}
0 & 0,31563657 & 0,177054 & 0,199197 & 0,308112 \\
0,100141 & 0 & 0,124839 & 0,169648 & 0,605369 \\
0,074565 & 0,1657133 & 0 & 0,584673 & 0,175047 \\
0,074532 & 0,200072 & 0,519450 & 0 & 0,205944 \\
0,096822 & 0,599959 & 0,130614 & 0,172963 & 0
\end{array}\right)\left(\begin{array}{c}
Z_{1}(t-1) \\
Z_{2}(t-1) \\
Z_{3}(t-1) \\
Z_{4}(t-1) \\
Z_{5}(t-1)
\end{array}\right)+\left(\begin{array}{c}
e_{1}(t) \\
e_{2}(t) \\
e_{3}(t) \\
e_{4}(t) \\
e_{5}(t)
\end{array}\right)
\end{aligned}
$$


Persamaan model GSTAR untuk kasus jumlah COVID-19 di 5 Provinsi Pulau Jawa menunjukkan bahwa jumlah COVID-19 masig-masing provinsi dipengaruhi oleh jumlah COVID-19 pada lokasi yang sama 1 hari sebelumnya dan 1 hari sebelumnya pada tiap-tiap lokasi lainnya. Selanjutnya adalah pemodelan GSTAR Pulau Sulawesi.

\section{Model GSTAR Pulau Sulawesi}

Berdasarkan Tabel 4 maka dapat dibuat bobot invers jarak dengan langkah sebagai berikut: 1. Melakukan pengkodean A: Sulawesi Selatan, B: Sulawesi Tengah, C: Sulawesi Utara.

2. Langkah selanjutnya adalah menghitung $d_{i j}$

Tabel 4. Latitude dan Longitude Pulau Sulawesi

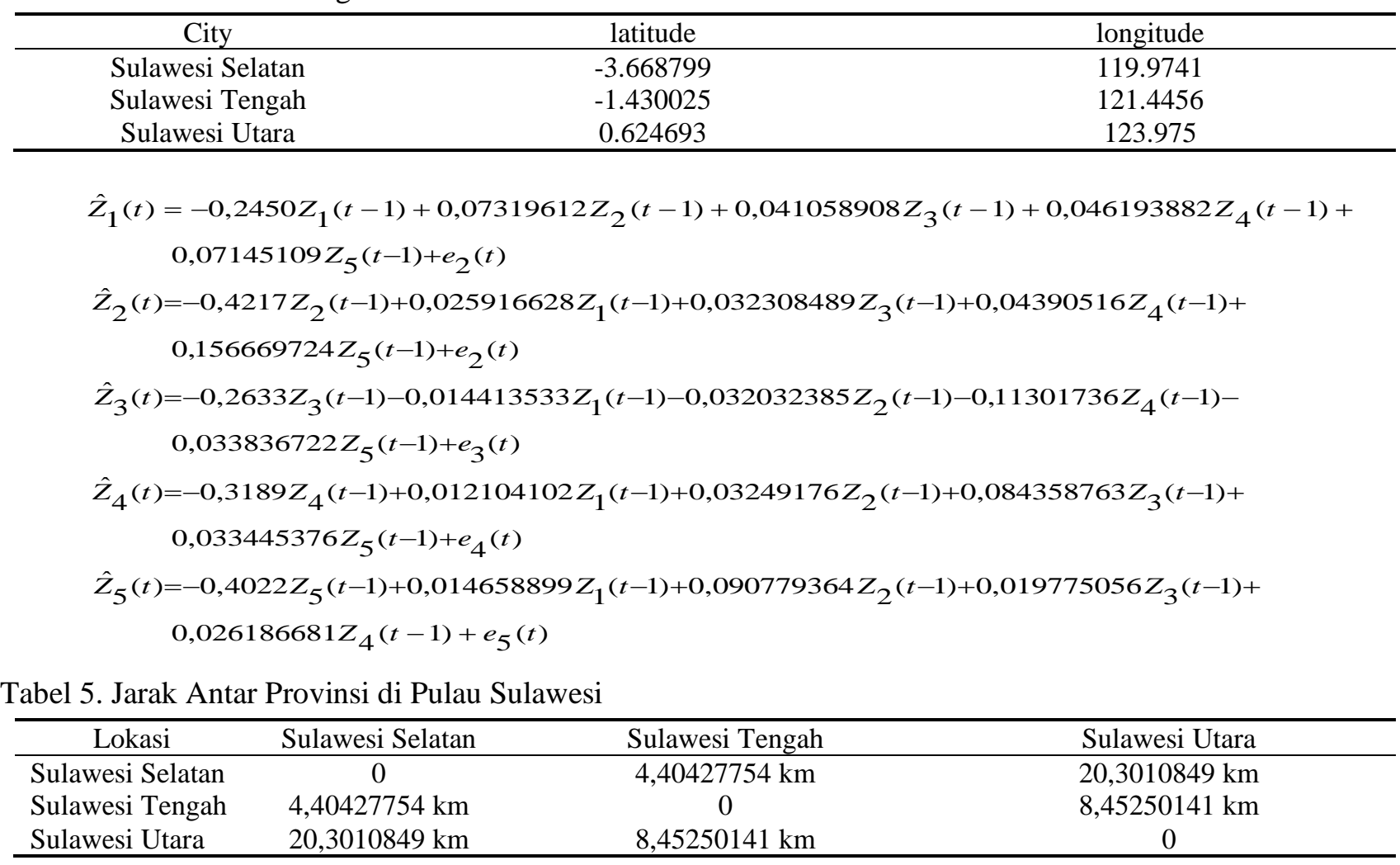

3. Langkah selanjutnya adalah menghitung $W_{i j}$ berikut:

Dari hasil perhitungan bobot invers jarak di atas maka dapat dibentuk matriks bobot invers jarak sebagai

$$
\mathbf{W}_{i j}=\left(\begin{array}{ccc}
0 & 0,821727872 & 0,178272128 \\
0,657435384 & 0 & 0,118308173 \\
0,29396338 & 0,70603662 & 0
\end{array}\right)
$$

Penaksiran parameter model GSTAR dilakukan dengan meregresikan variable $Z_{i}(t)$ dari data harian convirmed COVID-19 di 3 Provinsi pada waktu ke-t sebagai respon. Dengan menggunakan taraf kesalahan sebesar 5\% atau $\alpha=0,05$. Selanjutnya, hasil estimasi parameter model GSTAR menggunakan bobot invers jarak yang signifikan dapat dilihat pada Tabel 6 berikut:

Tabel 6. Estimasi Parameter Model GSTAR Menggunakan Invers Jarak

\begin{tabular}{cccccc}
\hline Parameter & Estimasi & Kesimpulan & Parameter & Estimasi & Kesimpulan \\
\hline$\phi_{10}^{1}$ & $-0,42707$ & Signifikan & $\phi_{11}^{1}$ & 0,09410 & Signifikan \\
$\phi_{10}^{2}$ & $-0,53532$ & Signifikan & $\phi_{11}^{2}$ & $-0,09211$ & Signifikan \\
$\phi_{10}^{3}$ & $-0,42521$ & Signifikan & $\phi_{11}^{3}$ & 0,17037 & Signifikan \\
\hline
\end{tabular}


Persamaan dalam bentuk matriks GSTAR untuk masing-masing lokasi (Sulawesi Selatan, Sulawesi Tengah dan Sulawesi Utara) sebagai berikut:

$$
\begin{aligned}
\left(\begin{array}{l}
Z_{1}(t) \\
Z_{2}(t) \\
Z_{3}(t)
\end{array}\right) & =\left(\begin{array}{ccc}
\phi_{10}^{1} & 0 & 0 \\
0 & \phi_{10}^{2} & 0 \\
0 & 0 & \phi_{10}^{3}
\end{array}\right)\left(\begin{array}{c}
Z_{1}(t-1) \\
Z_{2}(t-1) \\
Z_{3}(t-1)
\end{array}\right)+\left(\begin{array}{ccc}
\phi_{11}^{1} & 0 & 0 \\
0 & \phi_{11}^{2} & 0 \\
0 & 0 & \phi_{11}^{3}
\end{array}\right) \\
& \left(\begin{array}{ccc}
0 & 0,821727872 & 0,178272128 \\
0,657435384 & 0 & 0,118308173 \\
0,29396338 & 0,70603662 & 0
\end{array}\right)\left(\begin{array}{l}
Z_{1}(t-1) \\
Z_{2}(t-1) \\
Z_{3}(t-1)
\end{array}\right)+\left(\begin{array}{l}
e_{1}(t) \\
e_{2}(t) \\
e_{3}(t)
\end{array}\right)
\end{aligned}
$$

Oleh karena itu, model GSTAR (11)I(1) yang terbentuk adalah sebagai berikut :

$$
\begin{aligned}
& \hat{Z}_{1}(t)=-0,42707 Z_{1}(t-1)+0,777324593 Z_{2}(t-1)+0,016775407 Z_{3}(t-1)+e_{1}(t) \\
& \hat{Z}_{2}(t)=-0,53532 Z_{2}(t-1)-0,060556373 Z_{1}(t-1)-0,031553627 Z_{3}(t-1)+e_{2}(t) \\
& \hat{Z}_{3}(t)=-0,42521 Z_{3}(t-1)+0,050082541 Z_{1}(t-1)+0,120287459 Z_{2}(t-1)+e_{3}(t)
\end{aligned}
$$

Persamaan model GSTAR untuk kasus jumlah COVID-19 di 3 Provinsi Pulau Sulawesi menunjukkan bahwa jumlah COVID-19 masig-masing provinsi dipengaruhi oleh jumlah COVID-19 pada lokasi yang sama 1 hari sebelumnya dan 1 hari sebelumnya pada tiap-tiap lokasi lainnya. Perhitungan LJung-Box untuk melihat asumsi residual diperoleh dengan nilai p-value untuk Pulau jawa sebesar 0,5084 dan Pulau Sulawesi 0,1547 sehingga model di atas telah memenuhi uji asumsi residual white noise. Hal ini terlihat bahwa nilai p-value untuk lag-lag tersebut berada di atas $\alpha=0,05$ sehingga dapat disimpulkan bahwa asumsi residual terpenuhi. Proses peramalan ini dilakukan pada data out sampel dari model yang sudah didapat. Langkah selanjutnya adalah menghitung nilai ketepatan peramalannya dengan menggunakan nilai Root Mean Square Error (RMSE). Berikut hasil MSE dan RMSE untuk setiap model GSTAR. Nilai MSE dan RMSE di masing masing lokasi pada Tabel 7.

Tabel 7. Nilai MSE dan RMSE bobot Invers Jarak

\begin{tabular}{cccccc}
\hline Lokasi & MSE & RMSE & Lokasi & MSE & RMSE \\
\hline Bali $\left(Z_{1}\right)$ & 0,1041 & 0,3226 & Sulawesi Selatan $\left(Z_{1}\right)$ & 1,0287 & 1,014276 \\
DI Yogyakarta $\left(Z_{2}\right)$ & 0,0700 & 0,2647 & Sulawesi Tengah $\left(Z_{2}\right)$ & 1,4083 & 1,186748 \\
DKI Jakarta $\left(Z_{3}\right)$ & 0,1593 & 0,3992 & Sulawesi Utara $\left(Z_{3}\right)$ & 5,4001 & 2,323829 \\
Jawa Barat $\left(Z_{4}\right)$ & 0,1596 & 0,3995 & & & \\
Jawa Tengah $\left(Z_{5}\right)$ & 0,3169 & 0,56301 & & & \\
\hline
\end{tabular}

Tabel 8. Nilai MSE dan RMSE untuk data testing pada Bobot Invers Jarak

\begin{tabular}{ccc}
\hline Lokasi & MSE & RMSE \\
\hline Pulau Jawa & 0,1620465 & 0,40255 \\
Pulau Sulawesi & 2,612437 & 1,616303 \\
\hline
\end{tabular}

Tabel 8 Menunjukkan bahwa tingkat ramalan model GSTAR untuk semua data dengan bobot Invers Jarak yang memiliki RMSE terkecil berada pada model GSTAR Lokasi Pulau Jawa yaitu sebesar 0,40255. sedangkan ramalan model GSTAR yang memiliki nilai RMSE terbesar adalah Pulau Sulawesi yakni 1,616303. Langkah terakhir dalam analisis time series yaitu menentukan prediksi atau peramalan (forecasting) untuk periode selanjutnya. Berikut hasil forecasting pada jumlah kasus confirmed Covid-19 di pulau Jawa dan Sulawesi tanggal 1-7 Juli 2021 seperti pada Tabel 9.

\section{KESIMPULAN}

Model GSTAR $(1,1)$ orde satu merupakan model yang tepat untuk melihat keterkaitan jumlah penyebaran kasus COVID-19 di Pulau Jawa dan Sulawesi. Semua wilayah dalam suatu pulau yang diobservasi memiliki keterkaitan spasio temporal. Tingkat ramalan model GSTAR tersebut untuk semua data insample dan outsample dengan bobot Invers Jarak yang memiliki RMSE terkecil berada pada model GSTAR Lokasi Pulau Jawa yaitu sebesar 0,40255 . Sedangkan ramalan model GSTAR yang memiliki nilai RMSE terbesar adalah Pulau Sulawesi yakni 1,616303. 
Tabel 9. Hasil prediksi atau peramalan jumlah confirmed Covid-19 di Pulau Jawa dan Pulau Sulawesi Indonesia 1-7 Juli 2021

\begin{tabular}{ccccccccc}
\hline Waktu & Bali & $\begin{array}{c}\text { DI } \\
\text { Yogyakarta }\end{array}$ & $\begin{array}{c}\text { DKI } \\
\text { Jakarta }\end{array}$ & Jawa Barat & $\begin{array}{c}\text { Jawa } \\
\text { Tengah }\end{array}$ & $\begin{array}{c}\text { Sulawesi } \\
\text { Selatan }\end{array}$ & $\begin{array}{c}\text { Sulawesi } \\
\text { Tengah }\end{array}$ & $\begin{array}{c}\text { Sulawesi } \\
\text { Utara }\end{array}$ \\
\hline 1 Juli 2021 & 699,9419 & 439,912 & 2638,51 & 668,813 & 585,917 & 36,8923 & 50,7227 & 1,18782 \\
2 Juli 2021 & 320,38 & 373,777 & 765,9702 & 6,12711 & 216,1604 & 23,6923 & 29,42444 & 7,4439 \\
3 Juli 2021 & 97,74577 & 207,6626 & 191,717 & 57,77712 & 110,581 & 32,86576 & 14,0819 & 5,518037 \\
4 Juli 2021 & 21,8515 & 106,02 & 39,63366 & 30,3661 & 62,48164 & 24,8896 & 5,37397 & 2,3942 \\
5 Juli 2021 & 2,282321 & 53,87862 & 5,40869 & 11,40764 & 35,0863 & 14,76676 & 1,29402 & 0,417923 \\
6 Juli 2021 & 1,182471 & 27,8323 & 0,43564 & 3,48941 & 19,228 & 7,30531 & 0,21469 & 0,406197 \\
7 Juli 2021 & 1,13214 & 14,6127 & 0,732359 & 0,829101 & 10,3428 & 2,959806 & 0,544495 & 0,56441 \\
\hline
\end{tabular}

\section{DAFTAR PUSTAKA}

Anggraeni, D. (2013). Aplikasi Generalized Space Time Autoregressive (GSTAR) pada Pemodelan Volume Kendaraan Masuk Tol Semarang. Jurnal Media Statistik, No.2, Vol.6, 71-80, : https://doi.org/10.147/medstat.6.2.61-70,pdf.

Borovkova, S.A. et al., 2008. Consistency and Asymptotic Normality of Least Square Estimators in Generalized STAR Models. Journal Complication Statistica Neerlandica. Hal. 482-500.

Dinas Kesehatan SULBAR, 2021, Update Data Covid Sulawesi Barat, https://www.dinkes.sulbarprov.go.id/, diakses tanggal 20 February 2021.

Harahap, R. J., 2020, Karakteristik Klinis Penyakit Coronavirus 2019, Jurnal Penelitian Perawat Profesional, No.3, Vol.2, 317-324, : http://jurnal.globalhealthsciencegroup.com/index.php/JPPP.pdf.

Islamiyah, A.N., (2018). Pemodelan Generalized Space Time Autoregressive (GSTAR) dan Penerapannya pada Penderita TB Paru (BTA+) di DKI Jakarta. Jurnal Statistika dan Aplikasinya (JSA), No.2, Vol. 2, 36-48, : https://doi.org/10.21009/JSA.02205,pdf.

KEMENKES RI, 2020, Pedoman Pencegahan dan Pengendalian COVID-19, http://covid19.kemkes.go.id, diakses tanggal 22 Februari 2021.

KEMENKES RI, 2021, Situasi Terkini Perkembangan Novel Coronavirus (COVID-19). https://covid19.kemkes.go.id/document/donwload/cover, diakses tgl 20 February 2021.

Siswanto, E. dkk., 2019, Pemodelan Generalized Space Time Autoregressive (GSTAR) Seasonal Pada Data Curah Hujan Empat Kabupaten Di Provinsi Jawa Tengah, Jurnal Gaussian, No.4, Vol.8, Tahun 2019, 418 - 427, : http://ejournal3.undip.ac.id/index.php/gaussian.

Wei, W.W.S. 1994. Time Series Analysis Univariate and Multivariate Methods, Canada: Addison Wesley Publishing Company, Inc.

Wei, W.W.S. 2006. Time Series Analysis Univariate and Multivariate Methods. Canada: Addison Wesley Publishing Company, Inc.

World Health Organization, 2021, Penyakit Coronavirus (Covid-19), https://www.who.int/emergencies/diseases/novelcoronavirus-2019, diakses tanggal 19 February 2021.

Wutsqa, D.U. dan Suhartono, 2010. Seasonal Multivariate Time Series Forecasting on Tourism Data by Using Var-Gstar Model, Jurnal Ilmu Dasar, No.1, Vol.11, Pp,101-109.

Zhu, et al., 2020, A Novel Coronavirus from Patients with Pneumonia in China 2019. N Engl J Med, 382(8), 727-733, Shttps://doi.org/10.1056/NEJMoa2001017. 